\title{
THE FUTURE OF CITIES: THE ROLE OF STRATEGIC PLANNING
}

Working Paper

\section{Greg Clark}

International cities expert and advisor to global cities for OECD, Urban Land

Institute, The Brookings Institution, New York Metropolitan Global Advisory

Board, London Enterprise Partnership, among others

greg@gregclark.com

\section{ABSTRACT}

Long term strategic plans are enjoying a renaissance in cities across the world. The strategic plans of London, Paris, Auckland, Johannesburg, Sao Paulo, Singapore, New York, and Barcelona are all examples of different ways that cities try to plot their own future. But what are the key ingredients of a strategic plan and how are they developed?

Key Words: Strategic Plan. Future of Cities. Urbanism. Methodology. Technology. 


\section{THE WORLD AND ITS CITIES IN 2040}

It is difficult to overestimate the extent of urban change that is set to take place over the next thirty years. On the one hand, some cities in 2040 will be extraordinarily large, with populations of close to 40 million people, and sprawling conjoined agglomerations such as the Pearl River Delta in Southern China will permanently redefine the urban form. At the same time, other smaller established centres which have benefited from historic linguistic, cultural and political advantages, will have to adjust to a much more even global balance of urban power, more equably distributed between West and East, North and South. For all cities then, the acquisition of new roles and the achievement of day-to-day functionality will require more strategic management and foresight than ever.

All strategic thinking on urban designs, infrastructures and economies will have to digest a rapidly changing economic landscape. We can expect the trade and investment environment in 2040 to be characterised by unprecedented commercial intensity, brevity of competitive advantage, trimmed profit margins and pressure on cities to host environments conducive to speed and plasticity. A gradual convergence in labour costs, productivity and corporate taxation regimes between nations will generate new dynamics of competitiveness. Low trade and investment barriers, a highly efficient international logistics system, and a sophisticated global communications platform, will all be essential just to compete. It is innovation that will become the key differentiator, based on the capacity to host, foster and commercialise inter-disciplinary knowledge, technologies and processes. Both leading command centre economies, and emerging urban powerhouses in the BRIC countries, and the Gulf, will depend upon science and engineering talent, quality telecommunications infrastructure, and the entrepreneurialisation of much larger sections of their populations than before.

Alongside this economic terrain, in 2040, the challenge of sustainability will have become definitively and concretely urban. The environmental and psychological effects of climate uncertainty will make mean cities must move quickly to deliver serious climate change mitigation strategies, provide a 
business case for new transport technologies, and become much more resilient and self-sufficient. This task is complicated further by changing demographic trends which require far-sighted consideration of urban health systems, userfriendly urban design, electronic public services, and workforce population dilemmas. And, given young populations' newfound mobility and more fluid identities, cities also face more rigorous challenges in terms of quality of life, authentic 'placemaking', and distinctiveness.

\section{Ingredients of success?}

The future of cities, then, consists of a number of critical shared opportunities, risks and challenges. Looking forward, the next phase of global city management points towards a number of credentials that will need to be met for the next business cycle.

i. Connectivity and accessibility. As well as air links to all established and growing markets and regions, cities will require integrated airport, rail and road networks, with a combined capacity to successfully transport people and goods inwards and outwards without excessive congestion.

ii. Economic breadth. Cities' will require the infrastructure and talent for a diverse knowledge economy, that are flexible and responsive to future turbulence in global markets.

iii. Quality of life, place, and amenity. For cities to retain their domestically produced talent and be conducive to attracting globally mobile creative classes, they must maintain high-quality urban design, culture and amenity.

iv. Skills of labor force. Cities will need to better manage the divergent two-tier pattern of job prospects and instead capitalise on the latent 
power of dense labour markets, solving the dilemma of job-skill mismatches.

v. Innovation and creativity. Utilising the innovative potential of new scientific and R\&D industries, together with cultural, media and creative clusters, will offer major economic advantages in the new cycle.

vi. Business environment, entrepreneurship and city cost-base. Cities will need to maintain an internationally competitive tax regime, attractive real estate costs and a welcoming regulatory climate to ensure flows of capital and talent come their way.

vii. Image and identity. In a highly congested brand world, cities will need to do more to promote themselves originally and through effective awareness-raising mechanisms, such as global events.

viii. Leadership and implementation of strategy. City leaders and influential decision-makers need to grasp the new global terrain, and identify how their city fits within it. Leaders are responsible for heading up mechanisms that can facilitate city-to-city knowledge-sharing. It is more important than ever that city strategic planning is devised and managed in a holistic fashion and according to realistic time scales.

These eight themes are indispensable for the next two decades to meet predictable economic and social demands. There are also challenges that are much more durable and reflect a city's capacity to thrive throughout the 21st century, and all the much more unpredictable alterations in geopolitical equilibrium, economic balance, environmental burden and social expectation. From this longer term perspective new elements enter the equation.

(i) Openness to international populations - the presence of international labour resources, particularly those in managerial level operations, producer services and creative sectors, will remain crucial 
to the generalised capacity to innovate and assemble new ideas. Very few cities have developed specific strategies to achieve to attract and cultivate high calibre talent.

(ii) Power (and adaptability) of the city identity and brand. An inimitable brand presence generates a high global perception of place and urban lifestyle that survives shock damage. The visionary oversight of brand status enables cities to overcome associations with outdated economic or social activity.

(iii) Location and access to growing markets. Some cities, Miami, Singapore and Istanbul among them, are more advantageously located at points of interconnection than others. Those at nodal points are compelled to have an inter-regional orientation, while those at the margins may have to initiate more uncertain efforts to carve out a global niche.

(iv) Role in fostering/brokering international trade. Cities with the multi-lingual capabilities and the political influence to achieve or maintain key trading hub status - Hong Kong is one prominent example - have the authority and access to ideas to adapt to future change.

(v) Power and influence of language and regulatory/legal/financial systems. The role of future global language trends - whether towards Mandarin, Spanish, Arabic or English - remains a highly valuable commodity for cities. Similarly potential shifts away from the preference towards Anglo-American legal and regulatory apparatuses and financial procedures needs to be closely monitored. English may remain dominant among global financial and business communities for the next three decades, a prospect non-English speaking cities must address decisively. 
(vi) Depth of artistic, architectural and cultural endowment. Cultural power will continue to function as a key gauge to city success, Flair in fashion, art and music have a centuries-old record for attracting talent.

(vii) City-regional leadership and effective investment advocacy. Regional leadership - at public policy, business and civil society levels will be to ensure consistent investment attraction and urban transformation. City regions with a well-organised entrepreneurial class, for example, can successfully lobby for adaptive change within government. In developing cities, leadership will also be relied upon from the bottom-up, by civil society organisations and social enterprise leaders more capable of mitigating the ignominious effects of poverty.

(viii) Adaptation to climate change. Successful cities will anticipate the serious demands placed upon them by climate change, and achieve a more compact and more concentrated urban environment. Integrated land use planning and decisive steps towards energy and resourceefficiency are thought to be hallmarks of long-term best practice management.

(ix) Success in adjusting to shocks, and luck/skill in being on the right side of conflicts. Cities are key sites at which the effects of climate change, natural disaster and global terrorism can come together with devastating effect. While not easily planned for, the magnitude of effect on cities partly depends on developing systems that can implement a fast response to such events, so that their development trajectory is minimally affected. Arguably, success will be found in those cities that are well-placed in these areas of vulnerability - medical provision, climate change adaptation, fiscal prudence, education and diversity. 
(x) Investment in the city from all sources (including higher tiers of government). An urgent challenge for metropolitan regions is to gain investment-raising autonomy. Metropolitan governments' success is largely reliant upon their local fundraising capacity, rendered especially urgent given the increasingly mobility of corporations and high-networth populations.

This abundance of thematic challenges and policy interventions cannot all be tackled by individual departments and with individualised goals. They require an overarching thought process, which is where we now turn:

\section{The role of long range strategic planning.}

Long-term strategic planning is considered critical to responding to new challenges in cities around the world. Interconnected planning has emerged as especially urgent given the rapidly multiplying complexities and dependencies that world cities are immersed in - exacerbated by decades of urban sprawl, realignment of economic capabilities, and pockets of social exclusion. This new genre of holistic planning incorporates objectives of economic development, environmental sustainability, social cohesion and community purpose, and thus addresses the full range of perspectvies and possibilities on a city's future.

Spatial and strategic planning for larger cities and metropolitan regions is experiencing something of a renaissance. After several decades of disjointed, fragmented and overlapping governance and planning agendas, most global cities have made moves to integrate their policymaking structures and planning processes. Many major cities in both the northern and southern hemispheres have adopted this strategic governance tool in the past decade, because it offers several unique advantages over other forms of city planning:

- Future and long term. It looks into the future in ways which go beyond the usual vision of governments and public bodies and seeks to express 
the future demand for a wide range of public goods that can then be anticipated better in the present.

- Spatial and integrated. It uses a spatial lens to observe the interconnected and mutually reinforcing nature of both urban and metropolitan challenges and solutions. As such it provides the scope for observing economic, social, environmental, physical, and cultural trends from a single perspective, rather than relying on the whims of individual city departments. It also offers the potential for integrated public policy solutions that address multiple challenges and goals simultaneously, for example around the twinned issues of land-use and transport.

- New Energy. It creates the institutional energy to combine local and national level resources and levers, and to draw together public and private ambition in concerted action.

- Imagination and vision. It employs 'visioning', 'modeling', 'scenario building', and 'story telling' techniques to discover and consider possible alternative futures for a city or region. As such it can be used as a platform for deeper democratic participation and debate, and a mechanism to crystallise clear options for the future.

Successful long-term planning has already seen many successes in cities such as Barcelona, Johannesburg, Bogotá, and Berlin.

\section{The purpose of strategic planning.}

There are a number of interrelated answers that help to see what the value added purpose of strategic planning is. Eight reasons to undertake this exercise are immediately observable:

i. Strategic Plans provide a means to translate visions, values, and ambitions into practical programmes of governance, investment, and 
management. As such they can link the aspirations of politicians and citizens into one shared plan with practical delivery arrangements.

ii. Strategic Plans provides a means to think and plan long term, and act consistently over a long development cycle, within a culture which is often short term in nature. Strategic Plans can be the subject of 'multiparty agreements' that can span several business cycles and many electoral cycles.

iii. Strategic Plans are 'Integrated Plans' and provide a means to see linkages between different aspects of city development and to understand complex phasing and sequencing issues and critical paths to success. For example strategic plans often show links between land use, transport, housing and, environment, or between education, skills, economy, and productivity, or between planning, branding, and promotion. Because city governments often do control land-use planning, but may not control all other aspects of development, administration, and investment in the city, strategic plans are a means to use spatial tools both to integrate, to shape and influence other inputs.

iv. Strategic Plans provide a mechanism for prioritisation of key projects and interventions which will have most impact on long term priorities.

v. Strategic Plans help to overcome co-ordination failures in city government and wider city governance by acting as 'joint plans' between multiple departments of city government and between the city government and other entities, including central or Federal Governments.

vi. Strategic Plans are a communication tool that link past, present, and future and tell the story of the city and its development in ways which are visible and practical, allowing stakeholders and citizens to imagine the future of the city and major change with greater confidence. As such they 
also stimulate the creation of partnership organisations whose remit is to cultivate and transmit the optimal city image to a worldwide audience of investors, visitors, labour, and publics. They inculcate values of collaboration, energy, inclusiveness and strategic risk-taking into city brand and perception management.

vii. Strategic Plans provide a means to understand and articulate investment opportunities and priorities and to frame potential for joint investment between multiple parties. They should act as part of investment prospectus between different tiers of government and other sources of investment capital.

viii. Strategic Plans provide a common evidence base, and persuasive 'case', and a common time-cycle for other kinds of plans acting to improve the coherence of all planning overall and bring existing plans closer together.

\section{Practice and methodology of strategic planning for cities.}

Strategic planning depends on substantive collaboration between stakeholders in City, State, and National governments, business groups, civil society, economic forecasters and science. Because they aim to be long-term in nature they often require multi-party sign off and shared governance, even if leadership comes from a smaller group. It is important therefore to have some participative oversight on the Strategic Plan. The idea is that it should command enough consensus that it would be able to continue even if the party in power changes.

A strategic plan needs to consider from the outset how to generate a coalition of investment to trigger rapid momentum for urban change. Cities must therefore build the case to national government about the positive role their urban area has on jobs, output, revenues, and national competitiveness as a whole. A city's global and international roles, its gateway functions, and the roles 
it plays in human capital formation and attraction are often overlooked at state and national levels where such priorities do not appear on the radar.

A 'business case' for investment is therefore critical to a strategic plan's viability. In showing the dynamics of contemporary competition within a continent or region, cities can demonstrate why opportunities need to be localised with them otherwise they risk landing in other countries. They can also show how other cities within the country can leverage new sector growth or new housing design. Other areas of persuasion include around current or potential tax contribution, talent attraction, raising of national productivity standards, and potential to outsource niches or back office functions to other cities.

Decisive data research helps to prove the economic case. Successful advocacy for investment and land-use preferences requires independent data support and an agenda of long-term public perception maintenance.

Plans need to ground the strategic planning process around human themes of liveability, diversity and prosperity. Strategic plans, and their communication to relevant stakeholders, benefit from explaining and internalising their cities' human diversity and the opportunities this brings for trade, market knowledge and cosmopolitan place-making. They also should include the implications of diversity for public policy and human services, and new policies and interventions capable of delivering decisive change.

Strategic plans require a clear and workable proposition for building a city's national and international reputation as being a great place to work, invest, and start a business. Well crafted initiatives in this field focus on achieving a better environment for business, investing in better business inputs, better inter-governmental co-ordination, and opportunities for incentives. Incentive structures for graduate enterprise, business expansion, scientific talent and foreign direct investment all need to be worked through in advance for international-oriented cities to achieve the necessary scale. Within this initiative, the development of innovation monitoring and evaluation tools can keep a close watch on the extent to which the city is fostering a genuinely supportive entrepreneurial and risk-taking culture. 
Environmental considerations are sometimes just added on at the end of documents to fulfil basic commitments to sustainability, but there are opportunities to incorporate these environmental initiatives more creatively to the core of a strategic plan. Firstly, the long term value of a city's environmental assets can be brought out to show the economic shrewdness of protection and self-sufficiency. Secondly, the role sustainability can play in perception-building among institutions and mobile knowledge workers in a more ethically-minded future can be emphasised.

When considering land-use futures, strategic plans must negotiate the tension between different interests in the city. On the one hand real estate developers tend to argue that freedom to develop land in a wide range of locations is a means to be pro-business, but insights from economic geography demonstrate that density is much more likely to foster proximity, productivity and creativity and other urban spill-overs.

Although the majority trend is now towards densification, strategic plans in any trajectory must consider the key challenge of how to improve the availability of urban land for redevelopment. Mechanisms for accelerating the speed and certainty of planning decisions, and the deployment of a range of tools to reduce costs and risks to developers of redeveloping urban land, must be incorporated into the overall vision. Coupling green space provision with substantial efforts at urban redevelopment, provides an investor friendly approach to re-use to increase incentives. It also ensures that over the longterm sufficient housing construction will take place to counter the decline in rural or greenfield development. Overcoming regulatory inertia which prevents sufficient land from being freed up for development is essential.

Matching land-use plans to long-term strategic transport goals is vital to ensure mutual achievement. The funding regime for a city's transport action plan must be synchronised with the strategic planning time frame, to ensure that provision is allocated to the right areas. As such the achievement of a regional land-use vision requires a clear governance structure which integrates ministries to ensure priorities in agriculture, transport, tourism and natural heritage protection are dealt with evenly. Assurances for long-term land management developed through existing government structures, is important to 
implementation and the confidence of key stakeholders. An open, transparent yet authoritative agency can ensure land-use requests are dealt with efficiently and in accordance with overall goals.

The allocation of protected spaces for recreation or environmental purposes also depends on physical and economic accessibility, namely adequate public transport for connecting residents and new walking and cycling routes. Improved communications with cities' poor and ethnic minorities, through multilingual media dissemination, can alert communities who might otherwise be indifferent or sceptical, of the benefits of these protected spaces.

The role of tourism (including educational tourism) in helping to build international familiarity must be addressed. Providing a clear role for active business leadership in the city development path and governance is also critical.

\section{The role of scenarios and future thinking.}

Strategic planning reaches far into the future. Many of the proposals for addressing cities' challenges in strategic plans are innovative and game changing, but in order to work also require a grounding in a more detailed picture of where the world, and the city, might be in three to four decades time.

This picture can be effectively crystallised through the tool of city and cityregional scenario planning. Scenarios, as applied to cities, resemble a portrait of a future, replete with its own set of particular challenges, risks and opportunities. The concept of the scenario inherently assumes the future's unpredictability and capacity to surprise, and thus rejects the 'most likely' city-regional trajectory. Scenario planning is thus considered superior to traditional forecasting methods, as it can better grasp the complexity of an uncertain future, enabling a more holistic conversation about the associated challenges and opportunities. A handful of world-class cities have begun comprehensive scenario planning, seeking to enclose within the range of scenarios the full set of future possibilities.

Scenario-building exercises can be very useful to place the road to the future in a more compelling context. They allow city and regional planners to make 
contingency arrangements given each eventuality, such that the future can be met with robust policies. Scenario planning can help city and regional governments and organisations interpret their external environment more thoroughly, and keep them alert to shifts in trends. Leaders and strategists can then grapple with the 'known unknowns' for their cities' futures, and find a place for them in strategic planning. The range of scenarios present a framework for action, intended to help define a 'preferred future' and the multi-level policies and actions required to achieve it.

Cities and city regions which have developed scenarios for their long-term future include, London, Paris/Ile-de-France, Chicago, Frankfurt Rhein-Main, Singapore, Hong Kong and Madrid.

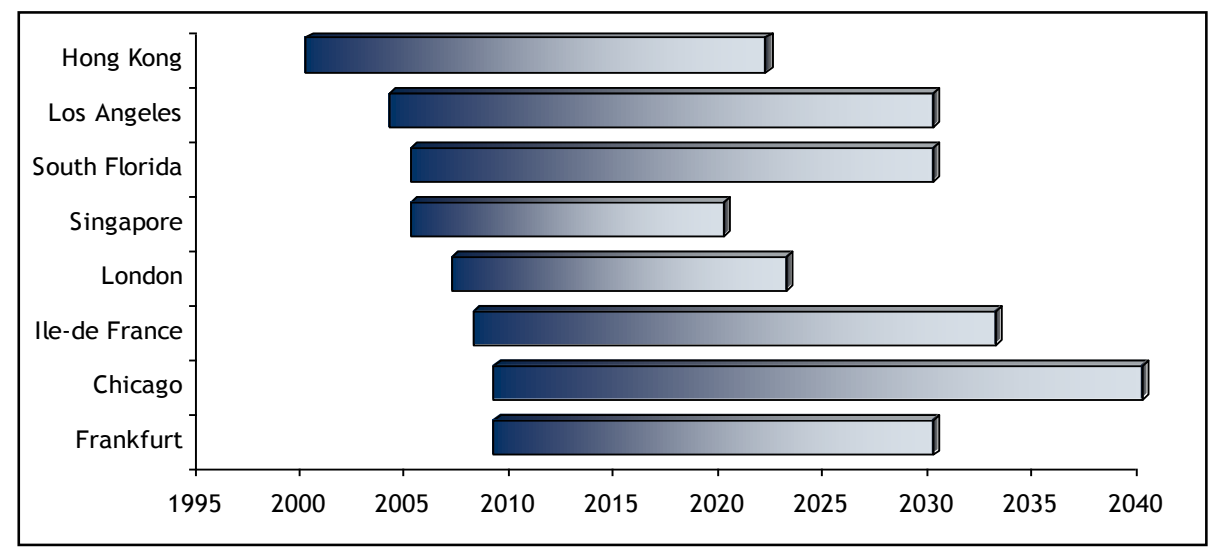

Figure 1: Regional Scenarios time-frames

Source: Elaborated by author (2012)

Scenario frameworks for cities can:

(i) demonstrate the risks of poor planning and the importance of a clear strategy along an enlightened 'middle path'.

(ii) Present the pros and cons to different growth types, oriented around the effect of growth on land use, mobility and the environment. They highlight the associated dangers of a poorly planned city region growth model. 
(iii) Focus on the impact of different policy approaches, such as the kind of specific investment strategy, the range of transport provision, and the degree of social/economic inclusiveness.

(iv) Be constructed around policy-independent trends that cannot be immediately controlled by government bodies, such as trends in the spheres of economics, social fabric, environment and security.

The motivation for carrying out the scenario exercise varies from city to city. In terms of its relationship to strategic planning, a scenario exercise is most valuable in stimulating a renewed stakeholder commitment to creating a regional vision. They can offer an opportunity for reflection on previous master plan successes and to test a future master plan's approach, structure, organisation and current prioritisation. Scenario development provides an agenda for public and business bodies to recognise the need of an agreed regional vision. They can also help embed future-thinking throughout the strategic planning process and city public service operationality, in some cases through a permanent dedicated futures office.

Scenario work carried out in the course of strategic planning among forwardthinking cities incorporates a number of drivers and inputs:

Population and demographic scenarios are the first input for planning to digest. Some cities in 2040 will be extraordinarily large. Tokyo, Shanghai, Mumbai and Beijing are set to lead the way with populations of close to 40 million people, while new hubs such as Chongqing and Kinshasa will join the world's biggest cities (McKinsey Global Institute, 2011; CNN GO, 2011). Meanwhile sprawling conjoined agglomerations will redefine the urban typology. The phenomenon is most advanced in the Pearl River Delta megalopolis, whose population even without adjacent Hong Kong will comfortably exceed 80 million by 2040. Comparable urban mergers around Beijing (Bohai Economic Rim), Osaka-Kobe-Kyoto, São Paulo-Rio de Janeiro, and Dhaka, will create unprecedented endless cities whose day-to-functioning will require ever more strategic management. But population projections are precarious, and need to be 
adjusted in the scenario-building process to take into account plausible political and social trends.

In the same way scenarios of how cities will age, and the resulting labour force and welfare structure, are important to how strategic plans reorient urban health systems and urban design to substantively accommodate older lifestyles and facilitate cohabitation of young and old. Such demographic concerns also influence the attitude towards community development and technologicallyenabled public services, which are significant although under-recognised elements to a city strategic plan.

Position in the global economic hierarchy also needs to be carefully accounted for in scenario exercises. Even by 2025, research shows that several of the world's richest cities in the twentieth century - including Miami, Milan, Atlanta and Detroit - will be falling rapidly down the global lists, to be first replaced by Singapore, Guangzhou, Shanghai and Beijing (Mckinsey Global Institute, 2011; PricewaterhouseCoopers, 2009). By 2040, the terrain may have changed even further, as large Chinese, Brazilian, Russian and Indian cities successfully combine size and economic dynamism. City strategies need to incorporate the full range of potential urban power balances, allowing for the historical dynamism of globalisation.

Rather than taking aim at historical or national rivals, plans must take into account which set of competitors their cities will possibly be pitched against in twenty or thirty years time, given growth trajectories, economic sector mixes and geographical roles. For example, as many Western cities gradually lose their comparative power and size advantage, their challenges must quickly shift towards outperforming others in terms of quality, specialisation, and distinctiveness. Scenarios therefore also help think about the role of labour costs, productivity and corporate taxation regimes among major cities and how to maintain competitiveness in a much more commercially intense environment. $A$ wide range of formulae and measures can assist in the comparative international positioning - such as the work of the Globalisation and World Cities Group, McKinsey Global Institute, Mercer Consulting, Jones Lang LaSalle, PwC and others. 
Economic trends and battlegrounds in the pursuit of innovation can be better understood through scenario projections. The precise character of conomic exchange in much more multi-polar and much more urbanised world in midcentury is the subject of much speculation, research and insight. The role of technology and communications in transforming work practices, consumer needs and logistics operations can be parsed out effectively through a series of scenarios. To what extent, for example, will the rolling out of computing power and telecommunications infrastructure to enable maximum economic participation and entrepreneurship be beneficial? Cities can use these scenarios to make adjustments to their design and investment agendas. Economic and space provision in cities will be much more effective if proper consideration of the role aging and environmental vulnerability will play on the growth of life sciences and clean technology, for example, and the cross-over opportunities between nano-, bio-, geo-, and information technologies. Equally city planning should be able to consider the preferred future forms of knowledge exchange and cater for such innovation ecosystems accordingly. In making allowances for future sector potential, strategic plans can invest in opportunities for sectors to pursue collaboration and interaction with the city itself, as residents and urban areas become test-beds for the latest inventions.

Relatedly, the preferences among diverse, cohesive and talented populations appears on the radar of city-regional aspirations through these scenarios. Good-case scenarios open up the horizon for cities to become paragons of cosmpolitanism which in turn can function as a key asset in economically unpredictable times. Scenarios incorporate deep concerns about migration patterns and can result in a prioritised effort to provide the highest incentives possible for mobile populations in high value-added sectors. Scenarios also identify the costs of social disintegration. Pessimistic scenarios can highlight the impact of pervasive social fragmentation, outward migration and increasing poverty, which among many things would lead to tourists and migrants choosing alternative destinations. Talent and skills choices also paint a picture of a city's future social mobility and community spirit. 
Scenario-building also facilitates a more reasoned approach to how to account for real-existing environmental challenges. A full survey of the social and psychological effects of climate change will enable city scenarios to consider the multi-dimensional importance of meeting low-carbon and climate change mitigation strategies. It will also provide a suitable business case for the uploading of new transport modes and technologies. As such they will help guide decisions as to whether electric, biofuel and hydrogen-powered cars are prioritised instead or as well as serious investment in public transport. Scenarios also prepare cities for prospect of needing to become much more self-sufficient. Assessment of specific climate change and pandemic risks may demand management and preparation for periodic spells of security emergency, food and water scarcity, and energy volatility. Whether the priority is deemed to be the local production of food, the preservation of agriculture and ex-urban farmland, or the embedding of smart grids, cities benefit from the evidence base of a scenario exercise that enables rapid adaptation.

The socio-environmental dimension needs to be particularly carefully evaluated in developing cities, where scenario exercises can enable far-sighted government. The sustainability of car-dependent cities can be taken into account more rigorously, compared to the cost and human capital demands of devising integrated multi-modal and IT-led mobility systems, or of rolling out comprehensive bus rapid transit systems. Similarly, scenario considerations can focus attention on social cohesion and the production of an authentic urban identity and value system which receives buy-in from all social classes and ethnicities. Because scenarios are integrative - that is, they combine trends in multiple fields to come up with plausible overall futures - they can plot the impact of personal technology access and social network ties and extrapolate the effects on political stability in highly unequal cities. They can also map the impact of potentially serious flooding, earthquake impacts, election-oriented violence, and long-term protracted refugee situations associated with conflict and displacement. Scenarios therefore offer a platform for sound management strategies, in this case in terms of humanitarian response, resettlement and urban (re-)integration (UN-Habitat, 2011). 
Scenarios also identify the sincere importance of high-capacity and collaborative metropolitan governance as the glue which can bind together the necessary facets of urban transformation in a strategic plan. Less favourable scenarios point to the dangers of fragmentation, duplication, sprawling subdivisions, and parochialism, which include economic inefficiencies, sociospatial division and pockets of de-skilling. These are contrasted to the effects of regionwide frameworks empowered to intervene to ensure housing supply, education and civic investment.

Finally scenarios have redirected policymaking attention to the subtle but important role of identity and branding as a driver of city success. Image retention is strongly correlated with inward talent and investment flows, in turn spurring the revitalisation of brownfield districts. Scenarios influenced by promotion issues also emphasise the importance of business-led institutional mechanisms to support innovative branding and awareness-raising.

In summary scenario-building initiatives can help advanced industrialised cities to examine the stability of their reliance on diversified economies, prolific physical infrastructure assets, quality higher educational and cultural institutions, and human diversity. They refocus policymakers' minds on the need to nurture a cutting-edge information economy, and stakeholder-led technology solutions for governance and infrastructural overstretch. Scenario exercises can also enable emerging cities to identify where best to make transformative impacts in the fields of transport, housing and sector-specific development. They also evidence the social and political importance of open-ness, identity and sustainability to meet uncertain dimensions of environmental volatility, rising cultural and political expectations, and a globalising rule of law.

\section{Critical themes in thinking about the future of cities}

The development strategy of a city region represents the clearest indication of its identity and future trajectory. Unsurprisingly, given the array of governance formats in global city regions, development plans come in many shapes and sizes. Some are simply a well presented list of vague and unimaginative 
objectives, while others name concrete policies, funding sources and targeted outcomes. The main differentiators are the degree to which they impact across the city region, and the degree to which they have support from the key institutional players, without which any plan is effectively a dead letter. In general, four categories of strategic plan can be found among global city regions:

i. Viable and actionable plan across the city region.

ii. Recognised city regional plan but lacking the finance or political will for implementation.

iii. Strong city or metropolitan plan with little consideration to the city region. Other sub-regions have their own development plans which are not necessarily harmonious with the city strategy.

iv. City-only plan that lacks an all-encompassing vision.

Only a small number of city regions have policy specific, government-backed development strategies. These regional plans direct the framework for all regional, town and local plans in the region, while national and inter-regional councils are typically embraced as important partners of territorial development. Such cases are certainly a minority. There are a number of lessons to be learnt from the recent limitations of world city region strategic plans.

i. The construction of a well-conceived metropolitan/regional plan is not itself a guarantee of an effective strategy in practice, as the experiences of Mumbai and Frankfurt Rhein-Main testify. Even if a region has clear objectives, it can struggle to turn sector recommendations into positive action. Often, implementation depends quite heavily upon other sector institutions, their resources and priorities, and there is evidence that in some cases not enough compels them to consider the recommendations of the city-regional plan. Plans that are not institutionally linked into the national frameworks can experience dramatically reduced effectiveness.

Frankfurt Rhein-Main is a case in point; its regional 'Strategic Vision' document, released in 2006, represented the first time in Germany that a 
land-use plan has been created for an entire region. Setting out the framework for the development of the region until 2020, its goals were agreed upon by all the municipalities of the region. However, the plan cannot escape its institutional territorial logic; the hands of regional planners are institutionally tied by administrative boundaries that cut through functional relations. As a result, the plan has struggled to address issues of conflict or controversy in the region (e.g the future of the airport), and can be seen more as a unifying device than a truly actionable regional development plan.

ii. A city region strategic plan needs to be policy specific, otherwise it can lead to rather nebulous conclusions. In recent years, several plans have been introduced by regional bodies on the themes of sustainable growth across metropolitan and regional boundaries. Many reports have been 'high-level overviews', rather than full of operable policies, and while indicative of a growing regional consciousness, are not on their own the basis for harmonious city regional development.

\section{iii. A strong regional plan must subsume the details of all city and} sub-regional development agendas. Several city regions have multiple strategies acting within them. Many North American regions, for example, have sought to develop plans alongside state and county land-use plans, which are implemented on a point-by-point, case-by-case, basis by local governments. This inevitably leads to co-ordination failures in regional development as different councils have different priorities and interpret planning advice in a variety of divergent ways. Historically, New York's strategic planning has struggled with this situation. Despite the robust research behind the RPA's 1996 Third Regional Plan plan's recommendations, many of the RPA's proposals received little support and recognition. Proposals were usually successful only when they (i) had an obvious revenue source, (ii) matched departmental funding cycles, and (iii) received high-level government support. Planning which serves to 
inadvertently weaken regional management has been witnessed in Sao Paulo. The metropolitan Strategic Master Plan of 2002 led to further fracturing of the administrative structure by failing to supervise the proposal of decentralisation. The plan has generated considerable divergence of policies and actions within the 39 municipalities that make up the city region, damaging metropolitan integration. 


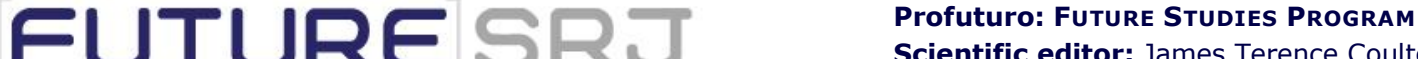 \\ Scientific editor: James Terence Coulter Wright \\ Evaluation: Double Blind Review pelo SEER/OJS \\ FUtURE STUDIES RESEARCH JOURNAL: \\ Revision: Grammatical, normative and layout.}

\section{Comparison of recent strategic plans.}

The strategic plans of London, Paris, Auckland, Johannesburg, Sao Paulo, Singapore, New York, and Barcelona are among the most interesting and robust among global metropolitan areas, meeting most of the key criteria for success.

Derived from overlapping challenges of congestion, housing, energy sustainability and territorial imbalances, these eight plans incorporate many areas of current best practice. Many of the most pertinent drivers and goals for regional success are found in more than one of these plans, as the chart below shows. 
Table 1: Key strategic planning goals

Source: Elaborated by author (2012)

\begin{tabular}{|l|l|l|l|l|l|l|l|}
\hline & $\begin{array}{l}\text { Grand Paris } \\
\text { Plan }\end{array}$ & London Plan & $\begin{array}{l}\text { Barcelona } \\
\text { Metropolitan } \\
\text { Strategic Plan }\end{array}$ & $\begin{array}{l}\text { New York } \\
\text { PlanYC 2030 }\end{array}$ & $\begin{array}{l}\text { Singapore } \\
\text { Concept } \\
\text { Plan }\end{array}$ & $\begin{array}{l}\text { Sao Paulo } \\
2040\end{array}$ \\
\hline Spatial plan? & Yes & Yes & No & No & Yes & No & No \\
\hline $\begin{array}{l}\text { In tandem with other } \\
\text { plans on economic } \\
\text { devmt, environment, } \\
\text { transport? }\end{array}$ & No & Yes & Yes & No & Yes & Yes \\
\hline $\begin{array}{l}\text { Direct involvement of } \\
\text { national govt? }\end{array}$ & Yes & No & No & Yes \\
\hline $\begin{array}{l}\text { Direct involvement of } \\
\text { state/regional govt }\end{array}$ & Yes & No & Yes & No & Yes & No & No \\
\hline $\begin{array}{l}\text { Supported by } \\
\text { governance } \\
\text { changes/empowerment? }\end{array}$ & No & No & Yes & No & Yes \\
\hline
\end{tabular}




\begin{tabular}{|c|c|c|c|c|c|c|c|c|}
\hline & Grand Paris Plan & London Plan & $\begin{array}{l}\text { Barcelona } \\
\text { Metropolitan } \\
\text { Strategic Plan }\end{array}$ & $\begin{array}{l}\text { New York PlaNYC } \\
2030\end{array}$ & $\begin{array}{l}\text { Singapore } \\
\text { Concept Plan }\end{array}$ & Sao Paulo 2040 & Joburg 2040 & Auckland Plan \\
\hline Vision/Ambition & $\begin{array}{l}\text { 'The objective: to } \\
\text { build a city that } \\
\text { offers true quality } \\
\text { of life to be more } \\
\text { attractive and } \\
\text { environment } \\
\text { friendly. The } \\
\text { challenge: to } \\
\text { rehumanise urban } \\
\text { life.' }\end{array}$ & $\begin{array}{l}\text { 'Up to 2031, } \\
\text { London should } \\
\text { excel among global } \\
\text { cities - expanding } \\
\text { opportunities for } \\
\text { all, achieving the } \\
\text { highest } \\
\text { environmental } \\
\text { standards and } \\
\text { quality of life and } \\
\text { leading the world } \\
\text { in its approach to } \\
\text { tackling the urban } \\
\text { challenges of the } \\
21^{\text {st }} \text { century, } \\
\text { particularly climate } \\
\text { change' }\end{array}$ & $\begin{array}{l}\text { 'Global metropolis } \\
\text { and capital of } \\
\text { southern Europe } \\
\text { and Medi- } \\
\text { terranean' }\end{array}$ & $\begin{array}{l}\text { 'A greener, } \\
\text { greater New } \\
\text { York' }\end{array}$ & $\begin{array}{l}\text { 'An inspiring, } \\
\text { inclusive and } \\
\text { vibrant city' }\end{array}$ & $\begin{array}{l} \\
\text { Achieve a } \\
\text { development } \\
\text { pattern that } \\
\text { combines growth } \\
\text { with reduced } \\
\text { inequalities, } \\
\text { social inclusion } \\
\text { + sustainability }\end{array}$ & $\begin{array}{l}\text { 'A World Class } \\
\text { African City of } \\
\text { the Future - a } \\
\text { vibrant, } \\
\text { equitable city, } \\
\text { strengthened } \\
\text { through its } \\
\text { diversity; a city } \\
\text { that provides } \\
\text { real quality of } \\
\text { life, } \\
\text { sustainability for } \\
\text { all its citizens; a } \\
\text { resilient and } \\
\text { adaptive } \\
\text { society.' }\end{array}$ & $\begin{array}{l}\text { 'The World's } \\
\text { Most Liveable } \\
\text { City' - Fair, } \\
\text { Safe and } \\
\text { Healthy; Green; } \\
\text { An Auckland of } \\
\text { Prosperity and } \\
\text { Opportunity; } \\
\text { well-connected } \\
\text { and accessible; } \\
\text { beautiful, } \\
\text { culturally rich } \\
\text { and creative' }\end{array}$ \\
\hline $\begin{array}{l}\text { Key mechanisms } \\
\text { for success }\end{array}$ & $\begin{array}{l}\text { New figure-of-eight } \\
\text { metro line } \\
\text { connecting outer } \\
\text { subiurbs to inner } \\
\text { city and airports; } \\
\text { leverage of the } \\
\text { River Seine }\end{array}$ & $\begin{array}{l}\text { 20+ Opportunity } \\
\text { Areas to channel } \\
\text { job/housing } \\
\text { growth; ongoing } \\
\text { transport and } \\
\text { green space } \\
\text { investment }\end{array}$ & $\begin{array}{l}\text { Education; } \\
\text { Leadership; } \\
\text { innovative } \\
\text { governance; New } \\
\text { values; more } \\
\text { languages }\end{array}$ & $\begin{array}{l}\text { Physical infra- } \\
\text { structure } \\
\text { functionality; } \\
\text { Housing, } \\
\text { recreation } \\
\text { spaces, water } \\
\text { and power and } \\
\text { power systems, } \\
\text { reducing } \\
\text { congestion. }\end{array}$ & $\begin{array}{l}\text { Re-channel } \\
\text { urban traffic } \\
\text { flow; Job } \\
\text { lands; green } \\
\text { spaces for } \\
\text { leisure; high } \\
\text { efficiency and } \\
\text { superior } \\
\text { design building } \\
\text { principles. }\end{array}$ & \begin{tabular}{|l} 
River \\
revitalisation, \\
urban parks \\
within 15 mins \\
walk, service \\
provision on \\
periphery and \\
'city in 30 \\
minutes', \\
concept
\end{tabular} & $\begin{array}{l}\text { Mass public } \\
\text { transport and } \\
\text { smart } \\
\text { technologies to } \\
\text { drive principles } \\
\text { of resilience, } \\
\text { sustainable } \\
\text { development. } \\
\text { and compact } \\
\text { urban form. }\end{array}$ & $\begin{array}{l}\text { City centre } \\
\text { cultural and } \\
\text { transport boost; } \\
\text { socio-economic } \\
\text { uplift in } \\
\text { Southern } \\
\text { districts }\end{array}$ \\
\hline
\end{tabular}




\begin{tabular}{|c|c|c|c|c|c|c|c|c|c|}
\hline & & Grand Paris Plan & London Plan & $\begin{array}{l}\text { Barcelona } \\
\text { Metropolitan } \\
\text { Strategic Plan }\end{array}$ & $\begin{array}{l}\text { New } \quad \text { York } \\
\text { PlanYC }\end{array}$ & $\begin{array}{l}\text { Singapore } \\
\text { Concept Plan }\end{array}$ & $\begin{array}{ll}\text { Sao } & \text { Paulo } \\
2040 & \end{array}$ & Joburg 2040 & $\begin{array}{l}\text { Aucklanc } \\
\text { Plan }\end{array}$ \\
\hline \multirow{6}{*}{ 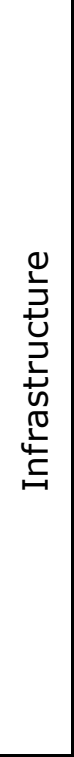 } & $\begin{array}{l}\text { Major house-building } \\
\text { programme }\end{array}$ & $\bullet$ & & & $\bullet$ & & & & $\bullet$ \\
\hline & Quality of life & $\bullet$ & $\bullet$ & $\bullet$ & $\bullet$ & & $\bullet$ & $\bullet$ & v \\
\hline & Improved urban design & $\bullet$ & & & $\bullet$ & $\bullet$ & $\bullet$ & & $\bullet$ \\
\hline & $\begin{array}{l}\text { Keynote CBD } \\
\text { redevelopment }\end{array}$ & & & & & & & & $\bullet$ \\
\hline & Waterfront upgrade & $\bullet$ & & & $\bullet$ & & & & $\bullet$ \\
\hline & Technology infrastructure & & & $\bullet$ & $\bullet$ & $\bullet$ & & $\bullet$ & \\
\hline \multirow{2}{*}{ 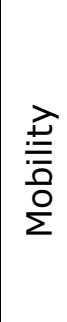 } & $\begin{array}{l}\text { High-investment public } \\
\text { transport, rail-focused } \\
\text { programme }\end{array}$ & v & & & & & $\bullet$ & $\bullet$ & $\bullet$ \\
\hline & $\begin{array}{l}\text { Transport projects, mixed } \\
\text { modes }\end{array}$ & & $\bullet$ & & $\bullet$ & $\bullet$ & $\bullet$ & & \\
\hline
\end{tabular}




\section{Critical success factors}

A series of imperatives for strategic plans show up in light of recent initiatives in this field:

i. Strategic plans are undoubtedly at their most effective when a city has a single purposeful plan which integrates the different strategies and plans into one framework which is underpinned by a core future evidence base and expressed as a single narrative. The coherence and mutual reinforcement of combined plans and strategies really matters. Their unification is enabled by not succumbing to the tempting idea that all decisions are trade-offs with zero-sum effects.

ii. Strategic plans need to recognise, understand and effectively allow for the functional interdependence of the various parts of the metropolitan region, its distinctive communities, and their particular contributions to regional success. Planning needs to grasp the actual day-to-day interactions of labour, housing, retail and supplier markets, and the catchment areas for CBDs, universities, airports, and hospitals. Strategic plans are successful if they can foster mutually beneficial relationships between the CBD and the airport, between suburbs and central city, and between urban and rural spaces.

iii. Strategic plans need to build collaborative leadership functions, whether through institutional co-operation or through reform of governance, or both. Strategic plans are most successful when they make headway in addressing co-ordination and integration failures. Often good results are achieved from a basis of common agenda setting and a commitment to joint action premised on shared accountability. 
iv. Strategic plans need support from higher tiers of government, which is best achieved through the presentation of a shrewd business case that invites greater engagement and participation from the national government alongside additional freedoms for the city-region itself. Often the creation of a special purpose agency to focus on territorial development, with input from all tiers of government and business/civic partners - is a valuable compromise solution which gains the suitable buy-in.

v. Central government and private sector engagement together must generate greater investment and financing capacity in order to move from a low investment/low return equilibrium to a high investment/high return equilibrium. The better use of financial innovations, assets, and the capturing of value to support long term investment are all necessary, and in many cases, the raising of additional levies and taxes for specific purposes which have clear benefits that justify costs is effective.

vi. Strategic plans cannot avoid the long-term fundamental functionality issues associated with skills, innovation, enterprise, and employment. These difficulties are often the most intractable and complex, but equally where the biggest rewards can be achieved. Support for these human capital dilemmas can be maintained through strategic planning's consideration of public services performance, the location of new industries, and connectivity development, all of which can support and reinforce skills and innovation.

vii. Strategic plans need project catalysts that can accelerate progress on solving key problems and utilise them to foster momentum fully. These might be specific urban developments, or events, that have the ability to deliver immediate and short term outcomes, but can also drive longer term goals in a given sub-region of a city. 
viii. Measurement and benchmarking progress regularly against agreed goals is essential to today's strategic planning matrix. This enables strategies to be responsive and to enables genuine achieved successes to be celebrated.

ix. Strategic plans must work to engage media attention towards the long term issues and trends facing the region rather than narrow and parochial issues that represent only the immediate manifestations of much wider challenges. Leaders and stakeholders that have taken the longer term bigger picture view of what is in the best interests of the interdependent city-region are to be encouraged.

x. Strategic plan success hinges upon a viable and ambitious identity that represents the essence of the urban area and can be promoted through major channels. Champions for the city, nationally and overseas, from both within and outside, have an especially significant dissemination impact.

\section{References}

Mckinsey Global Institute (2011). Urban world: Mapping the economic power of cities. Recuperado em 08 de agosto de 2013, em: http://www.ukmediacentre.pwc.com/imagelibrary/downloadMedia.ashx?Media DetailsID $=1562$.

PricewaterhouseCoopers (2009). UK Economic Outlook. Novembro, 2009. Recuperado em 08 de agosto de 2013, em: http://www.ukmediacentre.pwc.com/imagelibrary/downloadMedia.ashx?Media DetailsID $=1562$.

International Organization for Migration; United Nations Population Fund; UNHabitat (2011), 'The impact of global challenges and trends on humanitarian response'. Genebra, Suíça. Recuperado em 08 de agosto de 2013, em: http://www.un.org/en/ecosoc/julyhls/pdf11/has_concept_notepopulation_and_urbanization_in_humanitarian_settings.pdf. 